\title{
A contribution to the knowledge of the invertebrate cave faunas of Venezuela: Invertebrate faunas of tropical American caves, part. 4.
}

\author{
Stewart B. Peck*
}

SUMMARY

The invertebrate faunas of four caves in northern Venezuela were studied. Three were dry and one was a wet cave; but guano provided the base of the food chain in all four caves. The faunas in each were strikingly different. Of 24 non-accidental species of arthropods, all were judged to be troglophiles. All were scavengers except for 5 predators, one ectoparasite, and one parasitoid.

Comparatively little is known of the species composition of the invertebrate communities occupyng caves in the American tropics. A manuscript prepared by Philip Chapman (1978) on his field study of the invertebrate cave faunas of the Serrania de San Luis of Falcon State. Venezuela, has prompted me to submit a report on my field studies of some other Venezuelan cave faunas. I had the opportunity to investigate the invertebrate faunas of four caves during field work in March 1971 on catopid beetles in northern Venezuela. Since the composition of the invertebrate faunas of Venezuelan caves is not well known. I here offer an account of my collections and observations.

A review of much of the literature of Venezuelan cave invertebrates is presented in Chapman's paper which should serve as a companion to this one. The paper of Strinati (1971) must be mentioned as a starting point for modern tropical cave invertebrate faunal studies. Occasional issues of the Boletin de la Sociedad Venezolana de Espéleologia are an additional source of biological data not specificly cited by Chapman.

Department of Biology, Carleton University. Ottawa. Ontario, Canada K1S 5B6 


\section{CAVE SITES STUDIED}

Cueva Alfredo Jahn. The cave is located in a lowland rain forest region, about $20 \mathrm{Km} \mathrm{W}$ of the town of Curiépe $(80 \mathrm{Km} \mathrm{E}$ of Caracas), in the Acevedo district of Miranda State, $66^{\circ} 16^{\prime}$ 24" W long.; $10^{\circ} 28^{\prime} 45^{\prime \prime} \mathrm{N}$ lat., at $210 \mathrm{~m}$ elevation. The cave was formerly remote, but roads now penetrate to within a $2-3 \mathrm{~km}$ walk of the entrance. This is the second largest cave in Venezuela (the record is held by the famous Cueva del Guacharo with $10 \mathrm{~km}$ of passage), with about $5 \mathrm{~km}$ of mapped passage, mostly along the course of an underground river. A complete description of the cave, with map, and photographs, is given in vol. 4: 63-72 of the Bol. Soc. Ven. Espeleol., 1973. Bordón (1973) and Strinati (1971) present some data on its fauna. The cave river $\left(23^{\circ} \mathrm{C}\right.$ temp.) carriers much washed-in organic debris and guano; but no invertebrates were seen in the river. There are a few large and many small bat guano accumulations, including those of vampires. All support an abundant fauna. As an example, a $40 \mathrm{ml}$ sample of liquid vampire guano contained: 587 Drosophila larvae (5 ml volume), 97 milichiid fly larvae $(0.05 \mathrm{ml}$ vol.), 16 Drosophila eggs (0.75 $\mathrm{mm}$ long), 8 milichiid pupae (2 $\mathrm{mm}$ long), and 2 Fannia muscid larvae ( $2 \mathrm{~mm}$ long).

Cueva del Pico. The cave is located at about $10 \mathrm{~m}$ elev. on the Paraguaná Peninsula, Falcon State, not far along dirt roads from the sea coast at Balneario El Pico, a beach resort $3 \mathrm{~km} \mathrm{~N}$ of the town of Los Teques. The cave is in the strip of dry coastal desert, containing many large candelabra-like Cereus and abundant Prosopis (mesquite) leguminous shrubs. About $100 \mathrm{~m}$ of cave was studied. Bats were abundant and the cave floor was a solid blanket of dry guano with thousands of Zophobas and Alphitobius tenebrionid beetles. It was surprising that no filies, mites, or collembola were seen.

Cueva del Guano. This cave, at about $150 \mathrm{~m}$ elev., in a dry thorn-scrub thicket in the middle of the Paraguaná Peninsula, Falcon State, is near the village of Buena Vista. It is periodically mined by locals for guano. A single sink entrance slopes into a large chamber, where a guano floored tunnel proceeds to the terminal chamber in about $150 \mathrm{~m}$, containing tens of thousands of bats. The temperature was $36^{\circ} \mathrm{C}$. The guano fauna is distinctly different from that of the other caves visited in tha tenebrionids were absent, and flies, ants, isopods, and ticks were abundant.

Cueva de Piedra Honda. The cave is located at $120 \mathrm{~m}$ elev., 7 $\mathrm{km}$ SW of Pueblo Nuevo, near the village of San Jose de Cocodite, in a dry thorn-scrub forest on the Paraguaná Peninsula, 
Falcon State. Entry is by one of four shafts into four connected guano chambers. It is mapped to $200 \mathrm{~m}$ in length. and $14 \mathrm{~m}$ in depth (Bol. Soc. Ven. Espeleol. 4: 188-191, 1973). The guano fauna, with many cockroaches and carabid and elaterid beetles, was different from that of the previous caves. The bats were Natalus straminius, Mormoops megallophylla, Pteronotus davyi, and Leptonycteris curosae.

Generalities of Paraguaná Caves. The three caves studied in the Paraguaná Peninsula are similar in physical characteristics to those I have studied in the coastal plain of Florida (Peck, 1970), Georgia (Holsinger and Peck, 1971), and Alabama (unpubl.), and as reported by Hummelinck (1979) for the Netherlands Antilles. They are not very deep, in a coarse and poorly consolidated flat lying limestone, and in a land of low relief. The seldomly have standing water, and the rounded wall and ceiling contours suggest they were formed at the water table during an earlier and higher level of the sea. Entrances are often room collapses or smooth-walled wells. Shafts to the surface are common. The caves consist of a few large rooms connected by meandering tunnels. All the guano fauna was on that of insectivorous bats (only small amounts from flower-pollen feeding Leptonycteris). Fruit bats were absent and so were the insects that usually frequent the more moist habitats provided by fruit bat droppings. The guano fauna of each cave was markedly different.

\section{FAUNAL LIST}

Phylum Arthropoda

Class Arachnida

Order Acarina

Family Argasidae

Antricola silvai Cerny, E.L. Lindquist det.

Cueva del Guano, 7 specimens. These large ticks were found on guano, but are probably ectoparasitic at some time in their life cycle. Troglophile; ectoparosite, scavenger.

Order Aranea

Family Nesticidae, H. Levi det.

Genus and species undet.

Cueva Alfredo Jahn. These spiders were frequent on webs on the walls in the dark zone, often with six-sided egg sacks.

Troglophile, predator.

Class Crustacea

Order Isopoda

Family, genus, and species undetermined 
Cueva del Guano. Many small white terrestrial isopods with pale eyes were present on the guano. Troglophile, scavenger.

Class Diplopoda

Order Polydesmida

Family Cyrtodesmidae

Cyrtodesmus sp., H.F. Loomis det.

Cueva Alfredo Jahn. The collection is only of females, but probably is of an undescribed species. Troglophile, scavenger.

Class Insecta

Order Blattodea

Periplaneta americana, A.B. Gurney det.

Cueva de Piedra Honda. These cockroaches, native to Africa, were in abundant association with guano, and are widespread in tropical caves (Peck, 1974, 1975). Troglophile, scavenger.

Order Hemiptera

Family Cydnidae

Cyrtomenus bergi Froeschner, R.C. Froeschner det.

Cueva Alfredo Jahn. Cueva Piedra Honda. The species is widespread through tropical America (Froeschner, 1960). These burrowings bugs were associated with guano accumulations, but what they feed on is not known. It is certainly neither plant roots nor living plant tissues, upon which most members of the family seemingly feed (Froeschner, 1960,). Troglophile, scavenger?

Family Lygaeidae

Pachybrachius consutus (Dallas), R.C. Froeschner det.

Cueva Alfredo Jahn. These large bugs were very common on cave walls, near guano piles. They may be predators but more likely they feed on seeds in fruit bat guano. Troglophile, scavenger?

Cligenes sp., R.C. Froeschner det.

Cueva Alfredo Jahn. These small bugs were extremely abundant in fruit bat guano, where they probably feed on seeds. The genus also occurs on fruit bat guano in caves in Trinidad (Scudder, Darlington, and Hill, 1976). Troglophile, scavenger.

Order Coleoptera

Family Carabidae

Oxycrepis sp., G. Ball det.

Cueva Piedra Honda. Five specimens of this pterostichine were taken on damp mud. It is usually found in wet leaf litter in lowland rain forest. Troglophile?, predator.

Abaris sp., G. Ball det.

Cueva Piedra Honda, one specimen. It keys to A. aequinoc- 
tialis, but is not this species and may be undescribed. The genus occurs in leaf litter in a variety of forest types. Accidental?, predator.

Family Hydrophilidae

Dactylosternum sp., probably subdepressum (Cast.), A. Smetana det.

Cueva Alfredo Jahn, several on wet guano. Troglophile, scavenger.

Family Histeridae

Phelister fairmairei Marseul, H.F. Howden det.

Cueva del Guano, 5 on guano. These are probably predators on flies in the guano and on bat bodies. Troglophile, predator.

Saprinus sp., H.F. Howden det.

Cueva Alfredo Jahn, seven on guano. Troglophile, predator. Family Staphylindae

Philonthus sp., A. Smetana det.

Cueva Alfredo Jahn, on guano. Troglophile, predator.

Family Leiodidae, subfamily Catopinae

Adelopsis bordoni Jeannel (1964), S. Peck det.

Cueva Alfredo Jahn. Sixty-four adults and 29 larvae were taken from three spots with a light scattering of black and sticky guano on rock or mud, about $25 \mathrm{~cm}$ across. They were not found in larger guano piles, and no other beetles were at those occupied by Adelopsis. They ran rapidly when disturbed, and some even flew. The species is known only from this cave, but will likely be found in forest habitats as well. Troglophile, scavenger.

Family Tenebrionidae Alphitobius diaperinus (P.), T.J. Spilman det.

Cueva del Pico, many on guano. This species is known (unpub. data) at least from guano in houses in Canada to caves in Texas and Puerto Rico. Another species occurs on guano on Antigua, B.W.I. It may feed on bat bodies more than on guano. Troglophile, scavenger.

Zophobas atratus (F.), T.J. Spilman det.

Cueva del Pico, common on dry guano. The species also occurs in caves in Puerto Rico (Peck, 1974). Troglophile, scavenger.

Family Elateridae

Conoderus stricturus (Cond.), E. Becker det.

Cueva Piedra Honda. Many species of this click beetle were found in dry guano, where larvae were also seen. It also occurs in a cave in Cuba (unpub. data, F. de Zayas leg.). Troglophile, scavenger. 
Order Diptera

Family Spheroceridae

Leptocera sp., H. Teskey det.

Cueva Alfredo Jahn and Cueva del Guano. These were in association with the guano. Troglophile, scavenger.

Family Drosophilidae

Drosophila sp. 1 and 2, repleta group, H.J. Teskey det.

Cueva Alfredo Jahn. These were associated with wet guano, and as larvae in liquid vampire guano pools. One of these species is the same as reported from Chilibrillo Cave, Panama, (Peck, 1971). Troglophile, scavenger.

Family Empididae

Drapetis (Elaphopeza) sp., H. Teskey det.

Cueva Alfredo Jahn. This is an undescribed species, taken at guano. Drapetis is known from guano in caves in Jamaica (Peck, 1975). Troglophile, scavenger.

Family Milichiidae

Genus and species undetermined, probably Pholeomya sp., $\mathrm{H}$. Teskey det.

Cueva Alfredo Jahn. No adults were found of this fly, whose larvae occurred in pools of vampire guano. Milichiid flies are common in caves in Jamaica containing wet guano (Peck, 1975). Troglophile, scavenger.

Family Muscidae

Fannia sp., H. Teskey det.

Cueva Alfredo Jahn. No adults were found of this fly, whose larvae were found in pools of vampire guano. Troglophile, scavenger.

Order Hymenoptera

Family Braconidae?

Genus and species undetermined, 11 specimens lost.

Cueva Alfredo Jahn. These small wasps which I have encountered in other tropical caves, probably parasitize fly larvae in the guano. Troglophile, parasitoid.

Family Formicidae

Hypoponera gleadowi (Forel), W.J. Brown det.

Cueva del Guano. Many specimens of this Old World tramp species occurred foraging on and near guano. Three other species of Hypoponera inhabit caves in Jamaica and Puerto Rico (unpub. data). Troglophile, predator-scavenger. 


\section{ACKNOWLEDGMENTS}

Carlos Bordón A. and Juan A. Tronchoni of the Sociedad Venezolana de Espeleologia helped with arrangments for cave work, and Carlos Bordón led the trip to Cueva Alfredo Jahn. Pascual Soriano accompanied me in cavés in the Paraguana Peninsula. Oscar Martini of Cordón is thanked for hospitality on the Paraguaná Peninsula. Travel to and in Venezuela was made possible by an operting grant to Professor Henry F. Howden, Carleton University, from the Canadian National Research Council.

\section{LITERATURE CITED}

BORDON, C. 1973. Fauna de le Cueva A. Jahn. Bol. Soc. Venezolana. Espeleol., 4: 72.

CHAPMAN, P. 1978. The invertebrate fauna of caves of the Serrania de San Luis (Edo. Faconl, Venezuela). Unpublished manuscript.

FROESCHNER, R.C. 1960. Cydnidae of the Western Hemisphere. Proc. U.S. National Museum, 111 (no. 3430): 337-680.

HOLSINGER, J.R. and S.B. PECK. 1971. The invertebrate cave fauna of Georgia. Natl. Speleol. Soc. Bull. 33: 23-44.

HUMMELINCK, P.W. 1979. De grotten van de Nederlandse Antillen. Uitgaven van de Natuurwetenschappelijke studierkring voor Suriname en de Nederlandse Antilen. no. 97, Natuurhistorsche Reeks, no. 1, 176 pp.

JEANNEL, R. 1964. Un capitode cavernicole nouveau de Venezuela. Ann. Speleol. 19: $773-780$.

PECK, S.B. 1970. The terrestrial arthropod fauna of Florida caves. Florida Entomol., 53: 203-207.

PECK, S.B. 1971. The invertebrate fauna of tropical American caves, part. I: Chilibrillo Cave, Panama. Ann. Speleol., 26: 423-437.

PECK, S.B. 1974. The invertebrate fauna of tropical American caves, part II: Puerto Rico, an ecological and zoogeographic analysis. Biotropica 6: 14-31.

PECK, S.B. 1975. The invertebrate fauna of tropical American caves, part III: Jamaica, an introduction. Int. J. Speleol. 7: 303-326.

SCUDDER, G.G.E., P.J.E.C. DARLINGTON, and S.B. HILL. 1967. A new species of Lygaeidae (Hemiptera) from the Tamana Caves, Trinidad. Ann. Speleol. 22: $465-469$.

STRINATI, P. 1971. Récherches biospéleologique en Amerique du Sud. Ann. Spéléol., 26:441-450. 